\title{
IMPLEMENTASI KURIKULUM BERBASIS TAUHID DI SD INTEGRAL YAA BUNAYYA PLOSOARANG KECAMATAN SANANKULON BLITAR
}

\author{
Khairul Umam \\ Program Pascasarjana Institute Agama Islam Tribakti Kediri
}

\begin{abstract}
Abstrak
Penelitian ini di bingkai dalam topik besar Kurikulum Pendidikan yang secara khusus melihat bagaimana Implementasi Kurikulum Berbasis Tauhid di SD Integral Yaa Bunayya Plosoarang Kecamatan Sanankulon Kabupaten Blitar, dengan meneliti langsung praktek Implementasi Kurikulum Berbasis Tauhid di sekolah yang bersangkutan.

Permasalahan yang diajukan dalam penelitian ini meliputi pertanyaan 1. bagaimana Kurikulum Berbasis Tauhid Di SD Integral Yaa Bunayaa Kecamatan Sanankulon Kabupaten Blitar, 2. bagaiamana Implementasi Kurikulum Berbasis Tauhid Di SD Integral Yaa Bunayya Kecamatan Sanankulon Kabupaten Blitar, 3. bagaiamana Hasil Implementasi Kurikulum Berbasis Tauhid Di SD Integral Yaa Bunayya Kecamatan Sanankulon Kabupaten Blitar.

Jenis pendekatan dalam penelitian ini adalah kualitatif. Sebagaimana arahan jenis penelitian kualitatif, maka data terkumpul di analisis dengan bekal senjata intelektual berupa teori sebagaimana ditampilkan dalam BAB II untuk mendapatkan berbagai uraian interpretatif sesuai kaidah penelitian ilmiyah yang logis dan rasional atas data yang dikumpulkan.

Akhirnya penelitian ini memperoleh temuan sesuai pertanyaan permasalahan yang pada garis besarnya dapat disimpulkan sebagai berikut.1) Kurikulum Berbasis Tauhid adalah kurikulum yang berlandaskan pada al-quraan dan sunnah sebagai sumber utama dalam mengambil sikap dan mengkonsep segala bentuk prangkat pembelajaran. 2 . Implementasi kurikulum berbasis Tauhid menggunakan tiga pendekatan yang dijadikan sebagai acuan Pertama Metode Tilawah kedua Metode Tazkiyah dan Tiga Metode Taklimah. 3. Ada lima karakter siswa hasil output dari kurikulum berbasis tauhid, Pertama karakter keagamaan, Dua karakter keilmuan, Tiga karakter keterampilan, Empat Shahihul Aqidah, Lima Mutakhallikun Bil quran Enam Mujiddun Fil ibadah Tujuh Da'i ilallah delapan Mulatzimun bil jamaah.
\end{abstract}

\section{Kata Kunci: Implementasi Kurikulum Tauhid}

\section{Konteks Penelitian}

Masalah pendidikan di Indonesia ibarat benang kusut. Banyak permasalahan yang terjadi di dalam pendidikan Indonesia bukan hanya sistem pendidikannya tetapi pelaku yang ada didalamnya. Lihat saja, banyak pelanggaran yang terjadi seperti banyak pelajar melakukan tawuran, narkoba, bahkan ada oknum guru yang seharusnya menjadi panutan justru melakukan pelanggaran yaitu membiarkan kecurangan yang terjadi saat UN dengan alasan agar para siswanya lulus $100 \%$. Sungguh, ini merupkan keadaan yang sangat ironis. ${ }^{1}$

Hal ini tidak lepas dari Sumber manusia yang ada di dalamnya, sebab sumber daya manusia yang berkualitas merupakan prasyarat dasar bagi terbentuknya peradaban yang lebih baik dan sebaliknya, sumber manusia yang buruk akan menghasilkan peradaban yang buruk. Melihat realitas pendidikan pendidikan di negeri ini masih banyak masalah dan jauh dari harapan. Bahkan jauh tertinggal dari Negara-negara lain.

(Dikutip dari kompas.com 24/September/2012) 1 
Berdasarkan hasil observasi, peneliti tertarik untuk melakukan penelitian di SD Integral Yaa Bunayya, karena SD Integral Yaa Bunayya merupakan satu-satunya Lembaga Pendidikan Dasar Islam di wilayah Kecamatan Sanankulon Kabupaten Blitar yang menerapkan kurikulum berbasis tauhid. Dengan mengusung Visi Exsellent With Integral Caracter based on the Tauhid education.

Yang menarik untuk diteliti di SD Integral Yaa Bunayya ini, karena kurikulum yang diterapkan di dalamnya memadukan subyeksubyek sekuler, baik yang berakar dari barat atau timur, kepada persetujuan religius dan teologis yang berakar pada Al Qur'an dan Sunah Nabi. Hasil yang sangat nyata dari upaya sistem tersebut adalah sentralitas Allah Subhanahu wata'alaa sebagai Tuhan dalam pemikiran seorang muslim atau yang disebut dengan Tauhid.

Berpijak pada pernyataan di atas, maka peneliti tertarik untuk mengangkat sebuah judul: "Implementasi Kurikulum Berbasis Tauhid Di SD Integral Yaa Bunayya Plosoarang Kecamatan Sanankulon Kabupaten Blitar".

\section{Fokus Penelitian}

Fokus penelitian ini meliputi 1) Bagaimana Kurikulum Berbasis Tauhid Di SD Integral Yaa Bunayaa Kecamatan Sanankulon Kabupaten Blitar. 2) Bagaiamana Implementasi Kurikulum Berbasis Tauhid Di SD Integral Yaa Bunayya Kecamatan Sanankulon Kabupaten Blitar. 3) Bagaiamana Hasil Implementasi Kurikulum Berbasis Tauhid Di SD Integral Yaa Bunayya Kecamatan Sanankulon Kabupaten Blitar.

\section{Tinjauan Tentang Kurikulum Berbasis Tauhid}

Peran yang sangat strategis dan fundamental dalam berjalannya pendidikan yang baik maka kurikulum memiliki peran dalam pencapaian tujuan karna baik atau tidaknya suatu kurikulum dilihat dari proses dan hasil pencapaian yang telah ditempuh.

Secara etimologis, kurikulum berasal dari kata dalam Bahasa Latin "curir" yang artinya pelari, dan "currere" yang artinya tempat berlari. Pengertian awal kurikulum adalah suatu jarak yang harus ditempuh oleh pelari mulai dari garis start sampai garisfinish.

Dengan demikian, istilah awal kurikulum diadopsi dari bidang olahraga pada zaman romawi kuno di Yunani, baru kemudian diadopsi ke dalam dunia pendidikan. Yang diartikan sebagai rencana dan pengaturan tentang belajar peserta didik di suatu lembaga pendidikan. ${ }^{2}$

\section{Implementasi Kurikulum Berbasis Tauhid}

Metode yang digunakan dalam kurikulum Berbasis tauhid ini mengacu pada proses tarbiyah ilahiyya, yaitu metode yang digunakan Allah dalam mendidik para rasulnya dalam mendidik umatnya, yaitu lewat proses Tilawah, Tazkiyah, dan Ta'limah. untuk pondasi pendidikan anak ini sebagaimana tercantum dalam QS. Al Jumu'ah: 2-3, yang meliputi tiga tahap: ${ }^{3}$

\section{Tilawah}

Yaitu mengantarkan anak didik untuk mengenal Allah Subhanahuwata'alaa lewat "ayat-ayat" atau pertanda-pertanda-Nya yang berada dalam Al-qur'an, alam semesta dan dirinya sendiri. Dengan memahami dirinya sendiri dan penciptaan alam semesta mereka diantarkan untuk merakan adanya Allah dalam seluruh aktifitas hidupnya. ${ }^{4}$

Akhir dari perjalan fase tilawah yaitu lahirnya suatu pernyataan yang penuh kesadaran sebagai pengakuan bahwa Tidak Ada Tuhan Selain Allah Yang Dikenal Dengan Syhadat Lailaha Illallah. Proses yang dilakukan pada pendekatan tilawah ini disesuaikan menurut tingkat pemahaman parasantri.

Suparlan. Tanya Jawab Pengembangan Kurikulum 2 \& Materi Pembelajaran. Jakarta: Bumi Aksara. hal 34

Depdik, Buku Induk Pendidikan Integral Hidayat- 3 ullah. HIm. 89 Ibid. HIm. $91 \quad 4$ 


\section{Tazkiyah}

Penyucian atau at tazkiyah dalam bahasa arab berasal dari kata Zakaa-YazkuZakaa-An yang berarti suci. At tazkiyah berarti

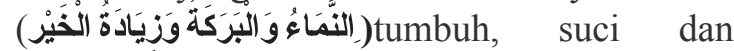

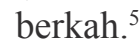

Ibnu Taimiyah menjelaskan bahwa at tazkiyah adalah menjadikan sesuatu menjadi suci baik zatnya maupun keyakinan dan fisiknya. Dalam pengertian dasarnya kata ini berarti tumbuh, berkembang, bersih. Ini bermakna, denganmengenal Allah Subhanahu wata'alaa anak didik akan tersucikan dari hal-hal yang dapat merusak dan pada saat yang sama berkembanglah potensi kebaikan. Mereka akan menjadi insan adab atau manusia beradab. ${ }^{6}$

Dalam metode Tazkiyah ini ditandai dengan adanya usaha keras membuang dan mengikis lima macam penghalang berfungsi dan berperannya syahadat, yaitu: ${ }^{7}$

\section{Tagha (Takabbur)}

Setiap orang yang belum mengerti fungsi dan hakekat benda atau materi yang belum mengenal dan memahami peran tuhan dalam hidupnya dipastikan mereka akan menjadi pecinta atau hamba dunia antara lain tandatandanya adalah orentasi berfikir selalu kepada dunia dan kesibukan hidupnya adalah urusan dunia (materi) ${ }^{8}$

Takabbur ini merupakan warna dasar yang dimiliki oleh setiap yang selalu memberikan dorongan atau rangsangan untuk merasa mampu dan hebat pantang disinggung maunya dipuji dan sanjung, berwatak sombong dan angkuh, sifat tagha inilah yang sring melahirkan persaingan dalam bentuk permusuhan yang menyebabkan timbulnya malapetaka dan musibah berupa pembunuhan sebagai tindak lanjut mental sadis dan kriminal yang mereka miliki.

5 Ibnu Taimiyah : Majmu al Fatawa. Saudi Arabia: Percetakan Mushaf Raja Fahd . 1416H, hlm.10-97.

6 Depdik, Buku Induk Pendidikan Integral Hidayatullah. HIm. 89

7 Ibid.

8 Ibid
Dengan demikian, bahwa Salah satu penyakit hati dalam diri manusia yang dapat menutup jalan hidayah Allah swt adalah sifat takabbur atau sombong. Penyakit ini bisa melanda seluruh lapisan masyarakat, dari yang kaya sampai yang miskin, orang alim dan bodoh, yang muslim maupun non muslim, dan lain-lainnya.Sombong adalah watak utama dari Iblis, sebagaimana yang diterangkan dalam banyak ayat dalam Al- Qur'an. Sifat sombong memang bisa hinggap pada siapapun, namun yang lebih dominan adalah mereka yang mempunyai banyak potensi.

\section{Cinta Dunia}

Setiap orang yang belum mengerti fungsi dan hakekat benda atau materi dan belum mengenal, memahami peran tuhan dalam hidupnya dipastikan mereka akan menjadi pencinta dan hamba dunia antara lain tandatandanya adalah orentasi berfikir selalu kepada dunia dan kesibukan hidupnya adalah urusan dunia (materi). ${ }^{9}$

Cinta dunia adalah sesuatu yang sangat berbahaya. Perhatikan sabda Rasulullah saw berikut ini: "Kalau begitu, bergembiralah dan berharaplah memperoleh sesuatu yang melapangkan diri kalian. Demi Allah, bukan kemiskinan yang aku khawatirkan akan menimpa diri kalian.

Ingatlah kita hanya hidup sementara di dunia ini, semua harta dunia yang kita banggakan, tidak akan kita bawa mati, hanya amal ibadah, dan amal kebaikanlah yang akan menemani kita hingga sampai hari kita dibangkitkan nanti.

Jadikanlah dunia hanya sebagai ladang akhirat kita, tempat kita mempersiapkan bekal untuk akhirat nanti. Ingatlah selalu, bahwa kelak kita akan dimintai pertanggungjawaban atas apa yang sudah kita lakukan selama kita hidup di dunia ini.

\section{Dominasi nafsu}

Sifat nafsu adalah tidak pernah merasa puas dan tidak pernah merasa miskin dari

9 Ibid. 
sekian banyak tumpukan keinginan yang tidak akan pernah tercapai keinginan nafsu itu maunya yang enak, bebas, santai, keinginanya dan kemauannya pantang dibatasi.utnuk mengikis dan mencegah dominasi nafsu pada setiap santri.

\section{Tumpukan dosa}

Setiap kesalahan yang dilakukan manusia akan menimbulkan noda pada dirinya dan apabila dibiarkan maka akan menjadi tumpukan kesalahan tumpukan itulah yang akan berproses menjadi watak kepribadian dan sifat mental kriminal yang mendatangkan keresahan.

\section{Kurang Mujahadan dan Riyadah}

Kebiasaan mental santai, acuh, memandang remeh dan enteng setiap masalah, tidak tampak adanya kesungguhan melaksanakan setiap pekerjaan, tidak memiliki dedikasi dan rasa tanggung jawab, tidak memiliki rasa kepercayaan adalah mental yang rusak dan negatif, mental sepeti ini jangankan mendatangkan hasil dan manfaat justru mereka yang memiliki mental ini akan menjadi beban masyarakat.

Karna itu adalah pendidikan "Wahyu" mental ini mendapat perhatian khusus untuk mengikis mental tersebut dapat ditempuh dengan cara memperbanyak lapangan kerja penugasan yang meminta keseriusan dalam berbagai sektor kegiatan pendidikan ditambah dengan pendidikan kepemimpinan. ${ }^{10}$

\section{Ta'limah.}

Abdul Fatah Jalal mengemukakan bahwa Ta'lim adalah proses pemberian pengetahuan, pemahaman. pengertian, tanggung jawab, dan penanaman amanah, sehingga terjadi penyucian (tazkiyah) atau pembersihan diri manusia dari segala kotoran yang menjadikan diri manusia itu berada dalam suatu kondisi yang memungkinkan untuk menerima al-hikmah serta mempelajari segala yang bermanfaat baginya dan yang tidak

10 Ibid.92 diketahuinya. ${ }^{11}$

Muhammad Rasyid Rida memberikan definisi ta'lim sebagai proses transmisi berbagai ilmu pengetahuan pada jiwa individu tanpa adanya batasan dan ketentuan tertentu. ${ }^{12}$

\section{Sejarah berdirinya}

Berjalannya Lembaga Pendidikan Islam (LPI) Yaa Bunayya Pesantren Hidayatullah Blitar ini tak lepas dari perjuangan panjang para pendirinya. Mereka adalah para santri yang ulet dan memiliki keyakinan yang besar terhadap masa depan Islam.

Lembaga ini dibangun dengan konsep tiga dimensi (Islamiah, Ilmiah, Alamiah) untuk mewujudkan cita-citanya yakni mewujudkan Lembaga Pendidikan Islam yang unggul dan kompetitif sehingga melahirkan generasi yang siap memikul amanah Allah sebagai hamba dan Kholifahnya dengan mengusung langkah menyelenggarakan pendidikan dengan system integral dalam aspek intelektual, spiritual dan life skills sehingga dapat melahirkan siswa muslim yang taqwa, cerdas dan mandiri.

Sekedar diketahui, pesantren Hidayatullah Blitar ini merupakan satu dari ratusan pesantren lainnya di bawah naungan organisasi kemasyarakatan (ormas) Hidayatullah. Induknya berada di Balikpapan Kaltim yang didirikan pada 7 Januari 1973/ 2 Dzulhijjah 1392, oleh almarhum Ustadz Abdullah Said.

Hadirnya SD Integral Yaa Bunayya Pondok Pesantren Hidayatullah ini disebabkan karena Saat ini belum banyak sekolah yang memberikan pendidikan secara intens untuk moralitas agama. Justru yang menjamur dewasa ini adalah berlombanya masing-masing sekolah untuk meraih prestasi akademik UAN. Sehingga suasana pendidikan tersebut kering akan nilai-nilai moralitas agama.

Sekolah yang diharapkan saat ini adalah sekolah yang bisa mentrasfer ahklak dan juga ilmu, sehingga anak tidak kering akan moralitas

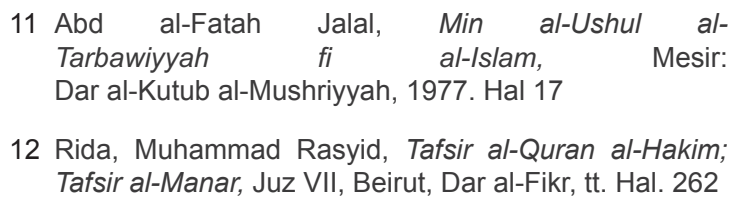

12 Rida, Muhammad Rasyid, Tafsir al-Quran al-Hakim; Tafsir al-Manar, Juz VII, Beirut, Dar al-Fikr, tt. Hal. 262 
agama tetapi juga tidak kalah bersaing dalam prestasi akademis. Perlu kita ketahui pekerjaan trasfer akhlak lebih berat dari pada tranfer ilmu.

Melihat situasi yang demikian, tak dapat dipungkiri lagi, Kurikulum pendidikan yang paling tepat saat ini adalah Kurikulum Berbasis Tauhid. Alasannya, karena dengan kurikulum inilah Siswa akan dikenalkan dengan TuhanNya sebagai pencipta dan pengendali kehidupan. Siswa dikenalkan dengan hukum-hukum-Nya, baik hukum dalam firman-Nya maupun hukum di alam ciptaan-Nya. Siswa dikenalkan dengan realitas persoalan kehidupan. Siswa diberikan cara menyelesaikan permasalahan kehidupan.

\section{Implemantasi Kurikulum Berbasis Tauhid}

Implementasi Kurikulum berbasis tauhid di SD Integral Yaa bunaya ini sebagai kurikulum utama Penerapan Kurikulum di SD Sementara kurikulum KTSP dari Dinas itu sebagai legal formal secara fungsi yaitu sebagai kurikulum pelengkap.

Kurikulum berbasis tauhid ini diterapkan di setiap mata pelajaran termasuk juga pelajaran eksta dan intra, setiap guru harus bisa membahasakan kepada anak-anak disetiap tema materi pelajaran yang diajarkan Tauhid mengenalkan allah di setiap materi yang diajarkan. Secara sederhana di mulai dari berdo'a kemudian diawali dengan tahfidzul qur'an setiap harinya, shalat dhuha, shalat wajib tepat waktu, dan bahkan setiap harinya aktivitas dan shalatnya anak-anak dipantau yaitu dengan diberikannya buku muhasabah harian, mentadabburi al qur'an di setiap tema materi yang diajarkan.

Pelajaran tidak hanya di dalam kelas saja tetapi Setiap aktivitas anak ada pelajaran di situ anak-anak tidak lepas dari pantaun guru sehingga guru lebih leluasa menegur anak-anak jika ia salah khususnya dalah hal syariat contoh cara bergaul anak laki-laki dan perempuan itu dipisah, adab makan, minum, berbicara, berjalan, tidak urak-urakan, tidak menghina dan mengolok-olok teman, bersikap jujur, menghormati guru dan lain-lain.

Ada tiga Metode yang diterapkan dalam kurikulum berbasis tauhid yang 1) Tilawah yaitu seluruh aktivitas pendidikan yang seluruh kegaiatan santrinya merupakan proses pencarian dan pengenalan TUHAN. Dengan kerja keras mereka diantarkan untuk merasakan kelemahan dirinya dan mengakui kekuasaan Allah SWT. 2) Metode Tazkiyah yaitu aktivitas pengecekan atau evaluasi yang sebenarnya. Dan berperannya syahadat itu dapat ditandai dengan lahirnya penyesalan atas seluruh kesalahan yang pernah dilakukan. 3) Metode Taklimahyaitu metode transformasi ilmu baik itu ilmu agama maupun ilmu umum, serta ilmuilmu terapan (Teknologi dan Keterampilan).

Kurikulum Berbasis Tauhid dalam pandangan SNW ini merupakan upaya sadar dan terstruktur serta sistematis untuk mensukseskan misi penciptaan manusia sebagai abdullah dan khalifatullah di muka bumi ini berdasarkan tuntutan wahyu Allah Swt. Sistem pendidikan seperti ini harus berasaskan tauhid, berwawasan integral dan merupaka bagian yang tak terpisahkan dari cita-cita membangun perdaban islam. ${ }^{13}$

Dalam praktek sehari-harinya, kurikulum berbasis tauhid ini menerapkan nilai-nilai tauhid ini menjadi pembuka, isi dan penutup pembelajaran. Sebagai pembuka, maka AlQuran selalu dibaca dan dibahas di awal ketika memulai pembelajaran setiap hari. Untuk pembentukan sikap bertauhid, maka setiap pembelajaran diawali dengan adab-adab yang baik, sesuai sunnah Nabi. Dan sebagai penutup, maka siswa harus diantar untuk bermuhasabah dan bersyukur pada Allah SWT.

Dan penerapan kurikulum ini tidak hanya di sekolah tetapi ketika di rumah juga anak-anak diharapkan nilai-nilai tauhid tetap dijalankan, karna ruang lingkup dalam kurikulum ini meliputi sekolah, keluarga dan masyarakat. Maka sebagai mentuk evaluasinya adalah anakanak diberikan buku muhasabah harian.

\section{Hasil Implementasi Kurikulum Berbasis Tauhid}

Tentunya disign dari kurikulum berbasis tauhid ini diharapkan bisa melahirkan gerasi

13 Rancangan Keputusan tentang konsep pendidikan hudayatullah.hlm 90 
yang cerdas, terampil dan mandiri, serta generasi rabbani yang cinta dan gemar menghafal al-qur'an.

Dan alhamdulillah SD integral yaa bunayya ini sudah meluluskan tujuh kali generasi dan setiap generasi bisa diterima di seluruh lembaga pendidikan tingkat pertama di mana pun.

Secara kemampuan hasil dari lulusan kurikulum berbasis tauhid ini tidak mengecewakan sebab secara intelektual bisa bersaing dengan lembaga-lembaga lain yang sudah maju dan mapan

Hasil dari implementasi kurikulum berbasis tauhid ini yaitu mencetak generasi Beradab dan Berprestasi sehingga menjadi Insan Kamil, profil out yang diharapkan dari kurikulum berbasis tauhid ini yaitu:

\section{a. Karakter Keagamaan}

Sesungguhnya agama (yang diridhai) disisi Allah hanyalah Islam. tiada berselisih orang-orang yang telah diberi Al Kitab,kecuali sesudah datang pengetahuan kepada mereka, karena kedengkian (yang ada) di antara mereka. Barangsiapa yang kafir terhadap ayat-ayat Allah Maka Sesungguhnya Allah sangat cepat hisab-Nya.

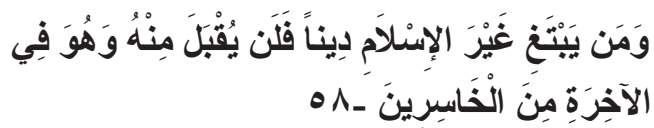

Artinya : Barangsiapa mencari agama selain agama Islam, Maka sekali-kali tidaklah akan diterima (agama itu)daripadanya, dan Dia di akhirat Termasuk orang-orang yang rugi $i^{14}$

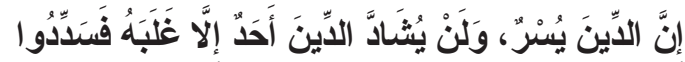

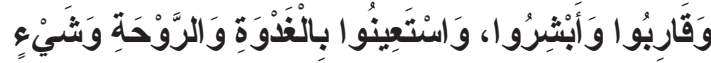

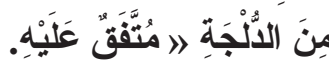

Artinya: Sesungguhnya agama ini mudah, dan tidaklah seseorang memberat-beratkan diri dalam beragama melainkan dia akan mengalahkannya. Maka, berlaku luruslah, berlaku sedanglah, bergembiralah, dan

14 .Alqur'n (Q.S ali Imran : 85) mintalah pertolongan pada waktu pagi, sore, dan sedikit pada akhir malam. "15

Memiliki karakter yang kuat dalam hal keagamaan, maka siswa yang diharapkan dari hasil kurikulum berbasis tauhid yaitu:

1) Memiliki pemahaman menyeluruh tentang Iman, Islam, dan Ihsan

2) Tumbuh kesadaran menjalankan ibadah, shalat, berdo'a dan dzikir

3) Senang membaca dan memahami AlQur'an

4) Hafal Al Qur'an Juz 29, 30 dan ayat-ayat pilihan

5) Tumbuh semangat berakhlakul karimah

6) Terbentuknya adab dalam menuntut ilmu

\section{b. Karakter Keilmuan}

Ilmu berasal dari bahasa Arab yaitu alima, yalamu, pilman) yang berarti mengerti, memahami benar-benar. Ilmu dari segi Istilah ialah Segala pengetahuan atau kebenaran tentang sesuatu yangdatang dari Allah Subhanahu wa Taala yang diturunkan kepada Rasul-rasulnya danalam ciptaannya termasuk manusia yang memiliki aspek lahiriah dan batiniah.

Ilmu dalam bahasa Inggris disebut science, sedangkan pengertian ilmu yang terdapat dalam kamus bahasa Indonesia adalah pengetahuan tentang suatu bidang yang disusun secara bersistem menurut metode-metode tertentu, yang dapat digunakan untuk menerangkan gejala gejala tertentu di bidang (pengetahuan) itu.

Imam Al-Ghazali juga memandang bahwa belajar atau menuntut ilmu adalah sangat penting serta menilai sebagai kegiatan yang terpuji. Untuk menerangkan keutamaan belajar tersebut Imam Al-Ghazali mengutip beberapa ayat Al-Qur'an, hadits Nabi serta atsar. Di antara ayat, hadits dan atsar yang dikutip tersebut, yaitu : Allah berfirman :

15 Al-hadis (HR. Bukhari Muslim) 


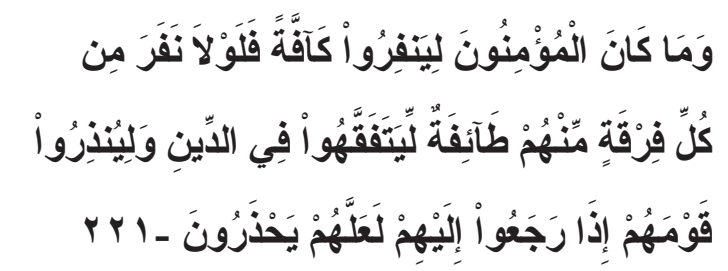

Artinya: Tidak sepatutnya bagi mukminin itu pergi semuanya (ke medan perang). mengapa tidak pergi dari tiap-tiap golongan di antara mereka beberapa orang untuk memperdalam pengetahuan mereka tentang agama dan untuk memberi peringatan kepada kaumnya apabila mereka telah kembali kepadanya, supaya mereka itu dapat menjaga dirinya. (QS. At-Taubah : 122)

Belajar atau menuntut ilmu mempunyai peranan penting dalam kehidupan. Dengan menuntut ilmu orang menjadi pandai, ia akan mengetahui terhadap segala sesuatu yang dipelajarinya. Tanpa menuntut ilmu orang tidak akan mengetahui sesuatu apapun.Di samping belajar dapat untuk menambah ilmu pengetahuan baik teori maupun praktik, belajar juga dinilai sebagai ibadah kepada Allah.

Orang yang belajar sungguh-sungguh disertai niat ikhlas ia akan memperoleh pahala yang banyak. Belajar juga dinilai sebagai perbuatan yang dapat mendatangkan ampunan dari Allah SWT. Orang yang belajar dengan niat ikhlas kepada Allah diampuni dosanya.

Demikian pentingnya belajar-menuntut ilmu ini sehingga dihargai sebagai jihad fisabililah yaitu pahalanya sama dengan orang yang pergi berperang dijalan Allah untuk membela kebenaran agama.

Memiliki karakter yang kuat dalam hal keilmuan, maka siswa yang diharapkan dari hasil kurikulum berbasis tauhid yaitu:

1) Tumbuh kesadaran bersikap dan bertingkah laku berdasarkan ilmu

2) Tumbuh semangat belajar, rasa ingin tahu tinggi dan senang melakukan observasi dan eksplorasi

3) Tumbuh sikap gemar membaca, menulis, berbicara, berfikir logis, kreatif dan inovatif

\section{c. Karakter Kemandirian}

Setiap mempunyai aktifitas dan kesibukannya masing-masing. Jadi, jika kita menemui suatu masalah atau kesulitan, cobalah menjadi orang mandiri dengan menyelesaikan masalah tersebut sendiri. Tapi jika kita tidak mampu untuk menyelesaikan-nya, barulah kita meminta saran atau nasihat kepada orang lain. Disinilah peran penting hidup mandiri dengan tidak menyusahkan orang lain dan menghadapi persoalan hidup dengan bijaksana.

Dengan membiasakan hidup mandiri, maka kita akan mendapatkan berbagai manfaat dan keuntungan. Berwibawa dan disegani oleh orang lain adalah salah satu contohnya. Adapun dengan hidup mandiri maka kita dapat mengambil suatu keputusan dengan tenang dan sesuai dengan apa yang kita harapkan. Sehingga kehidupan kita menjadi lebih baik dan harga diri kita semakin diperhitungkan (tidak dianggap remeh oleh orang lain).

Menjadi pribadi yang mandiri, maka siswa yang diharapkan dari hasil kurikulum berbasis tauhid yaitu: 1) Tumbuh jiwa kepemimpinan dan kemandirian 2) Terampil mengembangkan potensi sesuai minat dan bakat yang dimiliki

\section{Kesimpulan}

Setelah dilakukan pembahasan yang mendalam terhadap hasil penelitian yang berdasarkan rumusan masalah, dapat ditarik kesimpulan sebagai berikut:

1) Kurikulum Berbasis Tauhid adalah kurikulum yang berlandaskan pada alquraan dan sunnah sebagai pondasi utama dalam mengambil sikap dan mengkonsep segala bentuk prangkat pembelajaran. Sedangkan KonsepdariKurikulum Berbasis Tauhid ini berdasarkan atas Sistematika Nuzulnya Wahyu yang mana pradigma dari sistematika nuzulnya wahyu ini pendidikan harus ditata berasaskan Tauhid. Yakni suatu asas yang menjadikan Allah sebagai Sumber satu-satunya Ilmu. Allah SWT adalah sumber dari segala sumber. Dialah yang memberi ilmu, menetapkan metode berilmu serta menetapkan arah dan tujuan pemanfaatan ilmu tersebut pandangan terhadap kehidupan dunia (World 
View), Pemahaman, Penghayatan, serta Implementasi Ilmu dalam pola sikap, ucap dan tindakan, harus selalu mentauhidkan dan mengagungkan Allah SWT.

2) Dalam implementasi sehari-harinya, kurikulum berbasis tauhid ini menerapkan nilai-nilai tauhid, baik di saat pembukaan, isi dan penutup pembelajaran. Sebagai pembuka, maka Al-Quran selalu dibaca dan dibahas di awal ketika memulai pembelajaran setiap hari. Untuk pembentukan sikap bertauhid, maka setiap pembelajaran diawali dengan adab-adab yang baik, sesuai sunnah Nabi. Dan sebagai penutup, maka siswa harus diantarkan untuk bermuhasabah dan bersyukur pada Allah SWT.Ada tiga Metode yang diterapkan dalam kurikulum berbasis tauhid yang Pertama Tilawah yaitu seluruh aktivitas pendidikan yang seluruh kegaiatan santrinya merupakan proses pencarian dan pengenalan TUHAN. Dengan kerja keras mereka diantarkan untuk merasakan kelemahan dirinya dan mengakui kekuasaan Allah SWT. Dua Metode Tazkiyah yaitu aktivitas pengecekan atau evaluasi yang sebenarnya. Dan berperannya syahadat itu dapat ditandai dengan lahirnya penyesalan atas seluruh kesalahan yang pernah dilakukan. Tiga Metode Taklimahyaitu metode transformasi ilmu baik itu ilmu agama maupun ilmu umum, serta ilmu-ilmu terapan (Teknologi dan Keterampilan).

3) Hasil dari implementasi kurikulum berbasis tauhid ini yaitu melahirkan generasi yang Beradab dan Berprestasi sehingga menjadi Insan Kamil, profil out put yang diharapkan dari kurikulum berbasis tauhid ini yaitu. Pertama memiliki Karakter Ruhiyah matang dalam hal keagamaan kedua memiliki karakter aqliyah secara keilmuan memadai dan yang ketiga memeliki karakter Jismiyah menjadi pribadi yang mandiri.

\section{DAFTAR PUSTAKA}

Abd al-Fatah Jalal, (1977) Min al-Ushul al-Tarbawiyyah fi al-Islam, Mesir: Dar al-Kutub al-Mushriyyah,.

Ahmad Tanzeh (2009), Pengantar Metode Penelitian, Yogyakarta: Teras.

Al-Attas, Muhammad Naquib, (1992) Konsep Pendidikan dalam Islam, Bandung: Mizan,.

Arikunto Suharsimi.1989.Prosedur Penelitian: Suatu Pedekatan Praktek.Jakarta. Rineka Cipta.

Bahri, Syaiful \& Zain, Aswan (2005). Strategi Belajar Mengajar. Jakarta : Rineka Cipta.

Hadits riwayat Muslim (2961) dan al-Bukhari (6425), dan Ibnu Abi ad-Dunya dalam kitab tentang Zuhud : Raja Grafindo Persada.

Hamdani. (2011). Strategi Belajar Mengajar. Bandung : PUSTAKA SETIA http:// www.artikelind. com/2011/08/ diaksesn10 Juni 2016

Ibnu Taimiyah : Majmu al Fatawa. Saudi Arabia: Percetakan Mushaf Raja Fahd $.1416 \mathrm{H}$.

Imam Ibnu Jarir ath Thobari: Jami' al Bayan an Ta'wil Ayi al Qur'an. Beirut: Muassasah ar Risalah, $1420 \mathrm{H}$.

Imam Ibnul Qayyim al Jauziyah: Tafsir al Qur'an al Karim. Beirut: Daar wa Maktabah al Hilal. $1410 \mathrm{H}$.

Imam Imaduddin Ibnu Katsir: Tafsir al Qur-an al Adzhim. Daar thoyyibah li an nashr wa at tauzi', $1420 \mathrm{H}$.

Jami' al Bayan an Ta'wil Ayi al Qur'an, hal$24 / 457$.

Lexy J Moleong 2001, metodologi penelitian kualitatif, Bandung: PT. Remaja Rosda Karya.

LPI Hidayatullah, Ruhul Mudarrisu Ahammu Min Kulli Syai. Lembaga Pendidikan Integral Hidayatulla Se indonesia. 
Majid Abdul, Pendidikan berbasis Tauhid: Khutbah 'Idul Fitri 1 Syawal 1423 H./2002 M.

Mujib Abdul (1999), Fitrah dan Kepribadian Islam; sebuah Pendekatan Psikologis, Jakarta: Darul Falah.

Musa Yusuf (1961), Islam suatu kajian komprehensif (Terj.) ,Jakarta: Rajawali Press

Nana Syaodih Sukmadinata (2009), Metode Penelitian Pendidikan, (Bandung: PT Remaja Rosdakarya.

Nasution (2002), Metodologi Research Penelitian Ilmiah, Budi Aksara, Jakarta.

Nurdin Usman 2002, konteks implementasi berbasis kurikulum. Jakarta: PT Raja Grafindo Persada

Rida, Muhammad Rasyid, Tafsir al-Quran al-Hakim; Tafsir al-Manar, Juz VII, Beirut, Dar al-Fikr, tt.

Rida, Muhammad Rasyid, Tafsir al-Quran al-Hakim; Tafsir al-Manar, Juz VII, Beirut, Dar al-Fikr.

S. Margono (2005), Metodologi Penelitian Pendidikan, Rineka Cipta, Cet V, Jakarta.

Sanapiah Faisal (1990), Penelitian Kualitatif: Dasar-Dasar dan Aplikasi, YA3, Malang.

Sugiyono (2008), Metode Penelitian Pendidikan: Pendekatan Kuantitatif,dan Kaulitatif.

Suparlan. (20090) Pengembangan Kurikulum \& Materi Pembelajaran. Jakarta: Bumi Aksara.

Syah, Muhibbin (2003). Psikologi Belajar. Jakarta

Tim Pengembang Ilmu Pendidikan. (2007). Ilmu \& Aplikasi Pendidikan. Bandung: IMTIMA.

Tim Penyusun Kamus (1989), Kamus Besar Bahasa Indonesia, Jakarta: Departemen Pendidikan dan Kebudayaan

Ilicaes nusdae corite vellab ipis ide doluptate possitatus et, id qui occum vel ea nos maiosantia aperio conse aut voloribus re pe in estrumq uatures inciam quas des sitibea turiberumque sitas auda aut pos et facerepel magnati doluptam, quam in rest, as viti qui omni quo etur, nusaper atatem quias sundani mendant auditia epreperiorit quo cullanda quia dolla nimi, occate opta et as aliquam fuga. Senditiati berchic temoles trupti omnient eum ullupta tinventis corpor sus, cus dem quiam, que natisqui ipitatur, aut fuga. Aximolorro ea nusdam faccae et qui que nimolor ehentur?

Sini id que la ducium harum andemolor sequis molecta turibus vendam res int et ant, offictas ant maiosam eum, etus adit am, ad que siti odis as aut omni dundio conseque nis rehende res andaercipsam isitiis et, omnia sum qui omnis aut molupite eatur?

Nullam reptus, quasimus, od ut vendaes eatem quam ut ditin exerum que od quatem facea in con reheni nes et, ilignimus, voloritium estio. Ut qui num quat omni nim que de eos di dolupitatium fugiae es as que recaborum ut accum dis renditibus.

Catem ius, aut minciur ecestorese qui idi sust, sit qui aut alitates aliti anis nobistessit pos nit reniendam, aut volupta temquam, oditae reiciis samenis maionse quidem nist, que di bea consequunt faccum lab ipis velit aped quae maxim dolut remperatist qui qui ipsapit, quiam quid moluptae laut odi quuntio ressequiLuptaspidunt accatibusa que rem eturit occatus exerum est doluptur, estiberum fuga. Ut voluptature, quis aut aut videlicae eius 